\title{
A tree species with an extremely small population: recategorizing the Critically Endangered Acer yangbiense
}

\author{
Lidan Tao, Chunyan Han, Kun Song and Weibang Sun
}

\begin{abstract}
Acer yangbiense Y.S. Chen \& Q.E. Yang (Aceraceae) is a threatened tree species endemic to China, formerly presumed to have declined to only five extant individuals, restricted to Yangbi County, Yunnan Province. Our surveys in 2016, however, located 577 individuals in 12 localities, but only three localities (with a total of 62 individuals) are protected. Nine localities are on private forest land. The population's size structure is an inverse J-curve, but there is a scarcity of trees of the smallest size class and of seedlings. Our surveys also showed that the habitat of A. yangbiense is degraded as a result of the negative effects of agriculture, logging and wood harvesting. Assessment with the IUCN Red List categories and criteria indicates that $A$. yangbiense should be recategorized from Critically Endangered to Endangered.
\end{abstract}

Keywords Acer yangbiense, China, degraded, Endangered, size structure, threatened, tree, Yunnan

$\mathrm{M}$ ost of the species in the maple family (Aceraceae) are well known for their attractive foliage, and are widely cultivated throughout the temperate zone of the Northern Hemisphere (Sun, 2018). The two genera, Acer and Dipteronia, comprise 129 and two species, respectively; both genera and 101 species (63 endemic) occur in China (Sun, 2018). The Aceraceae are well represented in East Asia generally, and Acer is a widespread genus in the temperate zone of the Northern Hemisphere and some tropical regions (van Gelderen et al., 1994; Xu et al., 2008; Sun, 2018). The IUCN Red List of Maples (Gibbs \& Chen, 2016) evaluated 123 species (including the two species of Dipteronia), and found 54 species to be globally threatened. The threatened species list of China's higher plants (Qin et al., 2017) categorizes 45 taxa of Acer (including four subspecies and four

LidAN TAO ${ }^{*}$, ChUNYAN HAN ${ }^{*} \dagger$ and Weibang SUn (Corresponding author) Yunnan Key Laboratory for Integrative Conservation of Plant Species with Extremely Small Populations, Kunming Institute of Botany, Chinese Academy of Sciences, Kunming, Yunnan 650201, China. E-mail wbsun@mail.kib.ac.cn

Kun Song Department of Environmental Science, East China Normal University, Shanghai, China

${ }^{*}$ Contributed equally

$\dagger$ Also at: Guizhou University of Traditional Chinese Medicine, Guiyang, Guizhou, China

Received 8 September 2018. Revision requested 16 January 2019.

Accepted 21 January 2019. First published online 28 January 2020. varieties) as threated, with four taxa Critically Endangered and 14 taxa Endangered.

Acer yangbiense Y. S. Chen \& Q. E. Yang (Yangbi maple), a species described in 2003, is narrowly distributed in Malutang, Yangbi County, Yunnan Province, south-west China (Chen et al., 2003; Zhao et al., 2011). Despite extensive surveys only five wild individuals of A. yangbiense have previously been located and it is currently categorized as Critically Endangered on the IUCN Red List (Gibbs \& Chen, 2016; Qin et al., 2017) and categorized by the Yunann Government as one of the Plant Species with Extremely Small Populations, requiring urgent conservation (Ma et al., 2013; Sun, 2013). Because of habitat degradation resulting from rapid economic growth and overexploitation of natural resources, and potential stresses associated with climate change, conservation and rescue of threatened and narrowly distributed plant species in China is of some urgency (Sun et al., 2018). For rescuing A. yangbiense, in situ, near situ and ex situ conservation and population reinforcement and reintroduction have been employed since 2008 (Sun \& Yin, 2009; Yang et al., 2015; Sun, 2018). In addition, a parentage analysis of the five extant individuals and artificially propagated seedlings of $A$. yangbiense indicated that more individuals could be extant (Yang et al., 2015). We therefore carried out further surveys for $A$. yangbiense, as a result of which we have been able to reassess the species' conservation status.

During April-June 2016, based on former investigations, and information from local foresters in Yangbi county, we surveyed for A. yangbiense in the Cangshan and Laoheshang Mountains, in forests similar to those in which the species was originally found. In locations where we found the species, we recorded habitat characteristics, position (with a GPS), number of individuals, any apparent threats (using the Threats Classification Scheme; IUCN, 2018), sex, and the presence of any fruits. The extent of occurrence (EOO) of $A$. yangbiense in each locality was calculated following IUCN guidelines (IUCN, 2017), using Google Earth (Google, 2018) to measure the area contained within the shortest continuous imaginary boundary that encompassed all individuals. During October 2016-March 2018 we revisited the localities in which seedlings were observed in April-June 2016, to investigate the survival of these seedlings.

We measured diameter at breast height (DBH, measured at $1.3 \mathrm{~m}$ above the ground) of all individuals. Analysis of size-

This is an Open Access article, distributed under the terms of the Creative Commons Attribution-NonCommercial-ShareAlike licence (http://creativecommons.org/licenses/by-nc-sa/4.0/), which permits non-commercial re-use, distribution, and reproduction in any medium, provided the same Creative Commons licence is included and the original work is properly cited. The written permission of Cambridge University Press must be obtained for commercial re-use. 


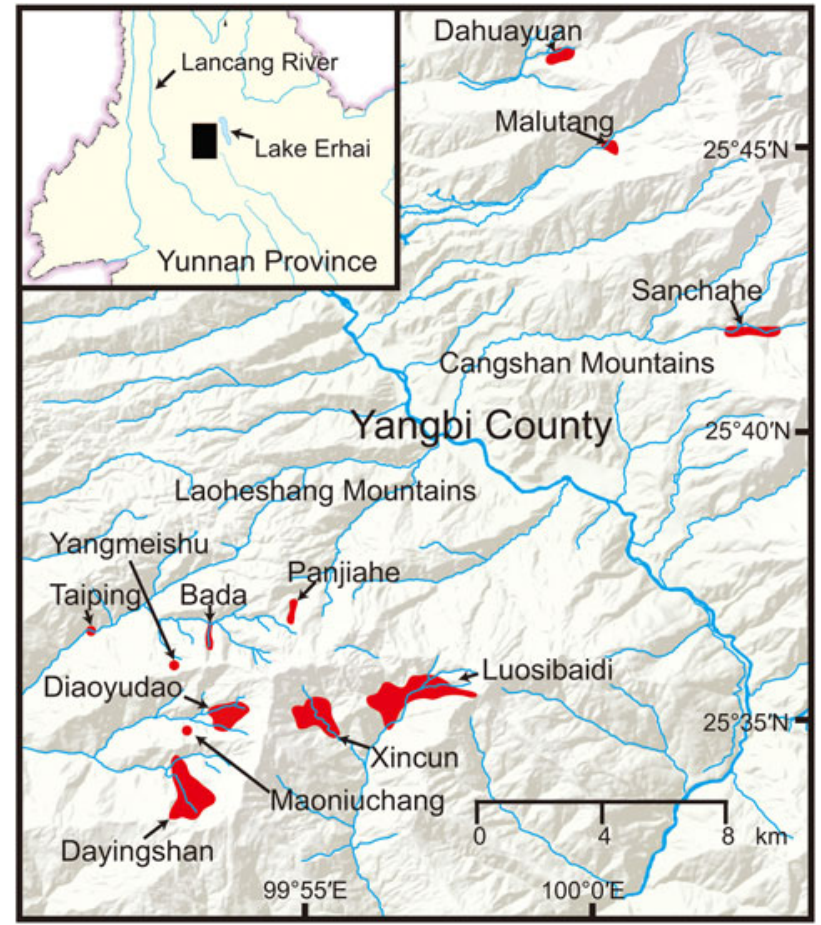

FIG. 1 The 12 localities in the Cangshan and Laoheshang Mountains where we found Acer yangbiense (Table 1), including Malutang, the only locality known prior to 2016.

class distributions followed Chien et al. (2008) and Qian et al. (2016). The populations in the two mountain ranges were each categorized into 10 size classes: seedlings as $<1.3 \mathrm{~m}$ height or $\mathrm{DBH}<2 \mathrm{~cm}$, eight 10-cm classes over DBH $10-90 \mathrm{~cm}$, and with the two individuals with a $\mathrm{DBH}$ of $90-160 \mathrm{~cm}$ as a single class. Using data on population size and size-class distributions, we assessed the extinction risk of $A$. yangbiense using the IUCN Red List criteria (IUCN, 2017).
We located 577 individual A. yangbiense in 12 localities, in 11 of which the species had not previously been recorded: 62 individuals in three localities in Cangshan Mountains, within Cangshan National Nature Reserve, and 515 individuals in nine localities in unprotected areas in Laoheshang Mountains (Fig. 1, Table 1). The species' EOO in these localities ranged from 0.01 (with only one or two individuals) to $1.5 \mathrm{~km}^{2}$. The total EOO of A. yangbiense is c. $226 \mathrm{~km}^{2}$. The principal threats we identified were small-holder farming (2.1.2), goat herding (2.3.2) and logging and wood harvesting (5.3.1). We observed that many individuals had been felled or lopped, with branches or even main stems cut. Most A. yangbiense were found near streams and on shady slopes in evergreen broadleaved forests. The main accompanying plant species were Illicium simonsii Maxim., Acer kungshanense Fang \& C.Y. Chang, Acer davidii Franch, Ageratina adenophorum (Spreng.) King \& H. Rob., Urtica fissa E. Pritz, Alnus nepalensis D. Don and Juglans sigillata Dode. In both Cangshan and Laoheshang Mountains the distribution of DBH exhibits an inverse J-shape, with a peak at $20 \mathrm{~cm}$ (Fig. 2). We found only four seedlings, in Malutang during 2016-2018, surrounded by farmlands and roads.

We have documented additional localities and individuals of A. yangbiense, and an inverse J-shaped DBH distribution potentially indicates a healthy population with natural recruitment (Geldenhuys, 1992; Sokpon \& Biaou, 2002). However, the $10 \mathrm{~cm}$ DBH class contains fewer individuals than the $20 \mathrm{~cm}$ class and we only located four seedlings, suggesting that the species may have recently declined and that regeneration may be poor. Local people indicated to us that 20 years previously, prior to felling of the species for building material and sale, A. yangbiense was more common.

We observed that A. yangbiense is androdioecious, with three types of flowers: male, female and sterile androgynous

TABLE 1 Characteristics of the 12 localities where Acer yangbiense was found in the Cangshan and Laoheshang Mountains in Yangbi County, Yunnan, China (Fig. 1), with the number of individual plants found.

\begin{tabular}{|c|c|c|c|c|c|c|}
\hline Region & Locality & $\mathrm{EOO}\left(\mathrm{m}^{2}\right)$ & Latitude $(\mathrm{N})$ & Longitude (E) & Altitude (m) & $\begin{array}{l}\text { No. of } \\
\text { individuals }\end{array}$ \\
\hline \multirow[t]{3}{*}{ Cangshan Mountains } & Malutang* & 25,415 & $25^{\circ} 44^{\prime} 56^{\prime \prime}-25^{\circ} 4503^{\prime \prime}$ & $100^{\circ} 00^{\prime} 15^{\prime \prime}-100^{\circ} 00^{\prime} 23^{\prime \prime}$ & $2,308-2,427$ & 5 \\
\hline & Dahuayuan & 11,655 & $25^{\circ} 46^{\prime} 33^{\prime \prime}-25^{\circ} 46^{\prime} 39^{\prime \prime}$ & $99^{\circ} 59^{\prime} 20^{\prime \prime}-99^{\circ} 59^{\prime} 34^{\prime \prime}$ & $2,429-2,540$ & 36 \\
\hline & Sanchahe & 31,951 & $25^{\circ} 41^{\prime} 44^{\prime \prime}-25^{\circ} 41^{\prime} 46^{\prime \prime}$ & $100^{\circ} 02^{\prime} 26^{\prime \prime}-100^{\circ} 03^{\prime} 08^{\prime \prime}$ & $2,291-2,383$ & 21 \\
\hline \multirow[t]{9}{*}{ Laoheshang Mountains } & Diaoyudao & 402,223 & $25^{\circ} 34^{\prime} 52^{\prime \prime}-25^{\circ} 35^{\prime} 10^{\prime \prime}$ & $99^{\circ} 53^{\prime} 20^{\prime \prime}-99^{\circ} 53^{\prime} 56^{\prime \prime}$ & $2,202-2,704$ & 153 \\
\hline & Panjiahe & 60,000 & $25^{\circ} 36^{\prime} 45^{\prime \prime}-25^{\circ} 37^{\prime} 03^{\prime \prime}$ & $99^{\circ} 54^{\prime} 46^{\prime \prime}-99^{\circ} 54^{\prime} 49^{\prime \prime}$ & $2,380-2,561$ & 21 \\
\hline & Yangmeishu & 100 & $25^{\circ} 35^{\prime} 58^{\prime \prime}$ & $99^{\circ} 52^{\prime} 43^{\prime \prime}$ & 2,545 & 2 \\
\hline & Dayingshan & 531,338 & $25^{\circ} 33^{\prime} 20^{\prime \prime}-25^{\circ} 34^{\prime} 17^{\prime \prime}$ & $99^{\circ} 52^{\prime} 44^{\prime \prime}-99^{\circ} 53^{\prime} 08^{\prime \prime}$ & $2,290-2,731$ & 116 \\
\hline & Maoniuchang & 100 & $25^{\circ} 34^{\prime} 48^{\prime \prime}$ & $99^{\circ} 52^{\prime} 57^{\prime \prime}$ & 2,384 & 1 \\
\hline & Xincun & 294,803 & $25^{\circ} 34^{\prime} 46^{\prime \prime}-25^{\circ} 35^{\prime} 10^{\prime \prime}$ & $99^{\circ} 54^{\prime} 52^{\prime \prime}-99^{\circ} 55^{\prime} 07^{\prime \prime}$ & $2,112-2,743$ & 108 \\
\hline & Taiping & 100 & $25^{\circ} 36^{\prime} 33^{\prime \prime}$ & $99^{\circ} 51^{\prime} 17^{\prime \prime}$ & 1,999 & 1 \\
\hline & Luosibaidi & $1,467,399$ & $25^{\circ} 34^{\prime} 53^{\prime \prime}-25^{\circ} 35^{\prime} 44^{\prime \prime}$ & $99^{\circ} 56^{\prime} 27^{\prime \prime}-99^{\circ} 57^{\prime} 10^{\prime \prime}$ & $2,290-2,543$ & 77 \\
\hline & Bada River & 20,471 & $25^{\circ} 36^{\prime} 17^{\prime \prime}-25^{\circ} 36^{\prime} 42^{\prime \prime}$ & $99^{\circ} 53^{\prime} 18^{\prime \prime}-99^{\circ} 53^{\prime} 22^{\prime \prime}$ & $2,400-2,573$ & 36 \\
\hline Total & & $226,032,306$ & & & & 577 \\
\hline
\end{tabular}

${ }^{*}$ The only locality known prior to 2016.

Oryx, 2020, 54(4), 474-477 ๔ 2020 Fauna \& Flora International doi:10.1017/50030605319000073 

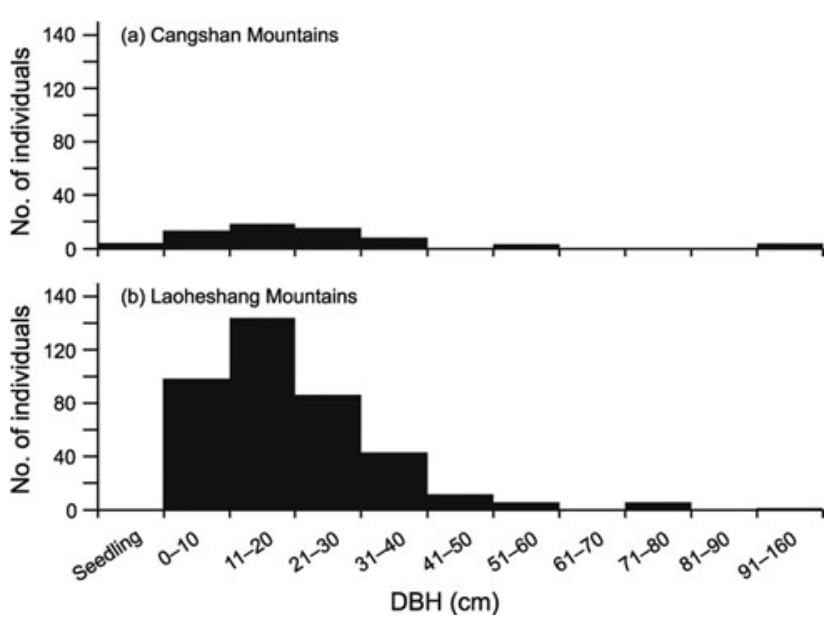

FIg. 2 The frequency distribution of the DBH of A. yangbiense in the Cangshan (a) and Laoheshang (b) Mountains. Trees that had regrown naturally following previous felling were not included. Seedlings were individuals $<1.3 \mathrm{~m}$ tall or with $\mathrm{DBH}<2 \mathrm{~cm}$.

flowers (the latter were few). Most trees bore male flowers only, few trees bore both male and female flowers, and others were not old enough for flowering. Of the 577 trees located, only $5.37 \%$ bore both male and female flowers. The reproductive system in Acer is diverse, and its evolution in the genus unclear (Renner et al., 2007). The low number of trees bearing female flowers could potentially exacerbate the threatened status of $A$. yangbiense.

Based on our findings, we reassess the extinction risk (IUCN, 2017) for A. yangbiense as Endangered based on criteria $\mathrm{C} 2 \mathrm{a}(\mathrm{i})$; i.e with $<2,500$ mature individuals $(\mathrm{C})$ and with a continuing decline inferred in numbers of mature individuals (2) and no subpopulation estimated to contain more than 250 mature individuals (a(i)). In addition, with $<5$,000 mature individuals in the wild and $<500$ in each isolated population, an extremely limited distribution range, pressures from habitat destruction, and occurrence in an area of high plant diversity and poor economic development (Ma et al., 2013; Sun, 2016; Yang \& Sun, 2017; Sun et al., 2018), A. yangbiense should continue to be considered as one of the Plant Species with Extremely Small Populations.

Seedlings of $A$. yangbiense had previously been propagated from only one tree (Yang et al., 2015). In 2016, based on information from our surveys, seeds were collected from several localities. Circa 50,000 seedlings were propagated in 2017, and in 2018 several thousand were reintroduced into wild areas near the species' original habitat. In addition, however, establishment of in situ protection for the currently unprotected localities needs to be prioritized.

Acknowledgments We thank the Dali Prefecture Cang Shan County Protection Administration and the Forestry Bureau of Yangbi County for their assistance. This study was supported by NSFC-Yunnan Joint Fund (Grant No. U1302262), Full Cover Conservation Project of Native Plants in Southwestern China
(KFJ-3W-No1), National Science and Technology Basic Resources Investigation Special Project (Grant No. 2017FY100100), Key Laboratory Construction of Yunnan Science and Technology Talents and Platform Program (Grant No. 2018DG004) and National Key R\&D Program of China (Grant No. 2017YFC0505200).

Author contributions Surveys and writing: $\mathrm{CH}, \mathrm{LT}$; revision: KS, WS. Conflicts of interest None.

Ethical standards Investigation and collection of specimens were with the permission and under the supervision of the local government, and this research abided by the Oryx guidelines on ethical standards.

\section{References}

Chien, P.D., Zuidema, P.A. \& NGhia, N.H. (2008) Conservation prospects for threatened Vietnamese tree species: results from a demographic study. Population Ecology, 50, 227-237.

Chen, Y.S., YAnG, Q.N. \& Zhu, G.H. (2003) Acer yangbiense (Aceraceae), a new species from Yunnan, China. Novon, 13, 296-299.

Geldenhuys, C.J. (1992) The use of diameter distributions in sustained-used management of forests: examples from Southern Africa. In The Ecology and Management of Indigenous Forests in Southern Africa: Processings of an International Symposium Victoria Falls Zimbabwe (eds G.D. Piearce \& D.J. Gumbo), pp. 154-167. Zimbabwe forestry Commission and SAREC, Harare, Zimbabwe.

Gib bs, D. \& Chen, Y.S. (2016) The Red List of Maples. Botanic Gardens Conservation International, Richmond, UK.

Google (2018) Google Earth Pro 7.3.2.5495. earth.google.com/ download-earth-pro.html [accessed 31 October 2018].

IUCN (2018) Threats Classification Scheme (Version 3.2). iucnredlist.org/resources/threat-classification-scheme [accessed 15 January 2019]

IUCN Standards and Petitions Subcommittee (2017) Guidelines for Using the IUCN Red List Categories and Criteria v.13. iucnredlist.org/documents/RedListGuidelines.pdf [accessed 15 January 2019].

Ma, Y.P., Chen, G., Grumbine, R.E., Dao, Z.L., Sun, W.B. \& Guo, H.J. (2013) Conserving plant species with extremely small populations (PSESP) in China. Biodiversity and Conservation, 22, 803-809.

Qian, S.H., YANG, Y.C., TANG, C.Q., Momohara, A., YI, S.R. \& OHSAWA, M. (2016) Effective conservation measures are needed for wild Cathaya argyrophylla populations in China: insights from the population structure and regeneration characteristics. Forest Ecology and Management, 361, 358-367.

Qin, H.N., YANG, Y., Dong, S.Y., He, Q., Jia, Y., ZhaO, L.N. et al. (2017) Threatened species list of China's higher plants. Biodiversity Science, 25, 696-744.

Renner, S.S., Beenken, L., Grimm, G.W., Kocyan, A. \& Ricklefs, R.E. (2007) The evolution of dioecy, heterodichogamy, and liable sex expression in Acer. Evolution, 61, 2701-2719.

Sokpon, N. \& Biaou, S.H. (2002) The use of diameter distributions in sustained use management of remnant forests in Benin: case of Bassila Forest Reserve in North Benin. Forest Ecology and Management, 161, 13-25.

Sun, W.B. (2013) Conserving Plant Species with Extremely Small Populations (PSESP) in Yunnan: A Practice and Exploration. Yunnan Science and Technology Press, Kunming, China. Sun, W.B. (2016) Words from the guest editor-in-chief. Plant Diversity, 38, 207-208. 
Sun, W.B. (2018) Conservation of Chinese maples: a case of Acer yangbiense, the typical PSESP (Plant Species with Extremely Small Populations) endemic to Yunnan in Southwest China. In Proceeding of the International Maple Symposium 2017 (ed. H. Angus), pp. 30-41. The Maple Society, Nottingham, UK.

Sun, W.B. \& Yin, Q. (2009) Conservation of the Yangbi maple Acer yangbiense in China. Oryx, 43, 461-462.

van Gelderen, D.M., De Jong, P.C. \& Oterdoom, H.J. (1994) Maples of the World. Timber Press, Portland, USA.

Xu, T.Z., Chen, Y.S., De Jong, P.C., Oterdoom, H.J. \& Chin, S.C. (2008) Aceraceae, Flora of China, vol. 11 (eds Z.Y. Wu \& H.R. Peter), pp. 518-553. Science Press, Beijing, China.
YANG, J. \& SUn, W.B. (2017) A new programme for conservation of plant species with extremely small populations in south-west China. Oryx, 51, 396-397.

YANG, J., ZhaO, L.L., YANG, J.B. \& Sun, W.B. (2015) Genetic diversity and conservation evaluation of a Critically Endangered endemic maple, Acer yangbiense, analyzed using microsatellite markers. Biochemical Systematics and Ecology, 6o, 193-198.

ZhaO, L.L., Sun, W.B. \& YANG, J.B. (2011) Development and characterization of microsatellite markers in the Critically Endangered species Acer yangbiense (Aceraceae). American Journal of Botany, 98, e247-e249. 